\title{
THE HAND THAT ROCKS THE CRADLE: MATERNITY, AGENCY AND COMMUNITY IN WOMEN'S WRITING IN GERMAN OF THE 1970s AND 1980s
}

\author{
EMILY JEREMIAH
}

\begin{abstract}
This article puts forth the idea of 'maternal performativity' as a way of going beyond pre-existing feminist conceptions of maternal agency. 'Agency' is important because, as numerous feminists have pointed out, the mother in Western culture has traditionally been conceived as passive and mute. I argue that challenging the traditional public/private divide is vital to the project of developing and enacting this maternal performativity, as the novels in question demonstrate. Where this opposition is left unquestioned, the texts suggest, mothers are marginal to the point of abjection. I look firstly at three texts in which mothers are depicted as utterly abject (Elsner, Pedretti, Beutler), then at two in which the idea of maternal agency is approached but ultimately jettisoned in favour of a resigned kind of essentialism (Struck and Frischmuth), and finally at one in which the mother is active and performative, but is still shown as hampered by traditional structures (Schroeder). The novels, and my article, thus performatively reveal the need for a maternal performativity to be acknowledged and practised.
\end{abstract}

The question of maternity represents a minefield for feminists, for whom it has become a matter of increasing urgency during the past few decades. The 'constructivism versus essentialism' opposition, which has both animated and bedevilled second-wave feminist thought, and which is as fruitful as it is false, ${ }^{1}$ leads only to new enquiries, like this one. Having long been aware of the constructed quality of maternal experience, where "constructedness' is not to be understood as a complete or final state, how can feminist analysis now theorise maternity in ways that permit the condition agency? Acknowledging constructedness might seem to be at odds with this project, for it is a move which problematises liberal notions of choice and individual freedom. What is needed, then, is a new conception of maternal agency, one which does not rely upon such liberal, essentialist assumptions. 'Agency' is important here, because, as numerous feminists have pointed out, the mother in Western culture has traditionally been conceived as a blank screen, a passive instrument. To show that mothers

\footnotetext{
${ }^{1}$ Diana Fuss, Essentially Speaking: Feminism, Nature and Difference, New York/London 1989, p. 1. Constructivism is the attempt to explain social institutions and practices as purely constructed, that is, as imposed from without onto allegedly prediscursive subjects. Essentialism rests on the belief that human beings are reducible to a single defining characteristic or set of characteristics which are innate. Constructivism involves essentialism, since it assumes the existence of prediscursive, 'untainted' subjects who are constructed by external forces.
} 
do something is already productively troublesome, in Judith Butler's sense of the word. ${ }^{2}$

To suggest that this maternal doing might be both valuable and subversive is to go one step further. Butler's notion of 'performativity' allows us to do just that. Performativity is 'the reiterative and citational practice by which discourse produces the effects that it names' ${ }^{3}$ It refers to those acts which serve to confirm and consolidate dominant discourses but which also reveal the fragility of these discourses, since these are shown to be dependent upon confirmation. Viewed in this light, maternity is a form of cultural performance, and "mother" is best understood as a verb, as something one does'. ${ }^{4}$ Mothering behaviours, according to this performative understanding, contain the potential for a disruption of dominant discourses on maternity, which depend upon their enactment for validity and which are, therefore, vulnerable, and open to change. Since motherhood $^{5}$ in Western culture has traditionally rested upon a number of key binary oppositions, such as man/woman, culture/nature, reason/emotion, mind/body, and - the main focus here - public/private, the implications are vast, involving as they do a challenge to traditional ideas of sex, corporeality, and kinship.

I argue here that maternal performativity is revealed as an absent ideal by the literary texts which I examine. Mothers in these novels are, largely, marginal to the point of abjection. ${ }^{6}$ The texts thus function as a critique of the organisation of mothering in the German-speaking countries in the 1970s and 1980s, serving also to point the way forward to a necessary alternative, which I proffer in the form of 'maternal agency'. Here, I am primarily concerned with how the texts in question negotiate the categories of public and private. I suggest that challenging the traditional public/private distinction is crucial to the project of developing the performative maternal agency outlined above, as the texts demonstrate. Where this opposition is left unquestioned, the texts imply, mothers are rendered mute and abject, and community - a form of multiple relationality which would serve to blur the traditional boundaries between public and private - is made unattainable.

The idea of 'tradition' must be viewed with caution, for the categories

\footnotetext{
${ }^{2}$ Judith Butler, Gender Trouble: Feminism and the Subversion of Identity, New York/London 1990, p. vii. 'Trouble' is understood by Butler as a potentially subversive form of disruption.

${ }^{3}$ Judith Butler, Bodies that Matter: On the Discursive Limits of "Sex", New York/London 1993, p. 2.

${ }^{4}$ Mielle Chandler, 'Emancipated Subjectivities and the Subjugation of Mothering Practices', in Redefining Motherhood: Changing Identities and Patterns, ed. Sharon Abbey and Andrea O'Reilly, Ontario 1998, pp. 270-86, here p.273.

5 'Motherhood' is understood here as an historically contingent body of social and institutional practices which constructs women's experience of mothering.

${ }^{6}$ A psychoanalytic term used by Butler to denote "those "unlivable" and "uninhabitable" zones of social life which are nevertheless densely populated by those who do not enjoy the status of the subject', Bodies that Matter, p. 3.

(c) Blackwell Publishers Ltd 2002.
} 
public and private are contingent and shifting. ${ }^{7}$ I suggest not that we abandon the latter terms, however, only that we always locate them in context and scrutinise them for the agenda which they might be representing. The construction and organisation of the modern nuclear family is bound up with economic, political and social factors operative in particular historical contexts; the family is, then, a construct, and one which serves particular interests, as feminists recognised long ago. Feminist responses to the modern nuclear family are also shifting and contingent, it should be noted. While nineteenth-century feminists celebrated domesticity and maternity, second-wave feminism has been more ambivalent, often, particularly in its early stages, stressing the damaging psychological effects of women's confinement to the private sphere. ${ }^{8}$ More recently, women's 'double burden' has been extensively and critically analysed. Being a working mother in contemporary Western ${ }^{9}$ societies, it has been argued, entails untenable psychological and emotional stress. ${ }^{10}$

Feminist discursive production has a crucial role to play in responding to and shaping material maternal practices. As Butler advises us, matter and discourse are indissoluble, since 'language both is and refers to that which is material'. ${ }^{11}$ Philosopher Sara Ruddick's 1989 Maternal Thinking offers an important discursive challenge to the public/private divide. Ruddick defines mothering as a type of work which 'begins in a response to the reality of a biological child in a particular social world'. She takes care to contextualise her own mothering, stressing that "people become mothers in particular historical and social circumstances'. ${ }^{12}$ Mothering cannot, then, be consigned to a purely private realm, and, as others point out, it takes place not only in the private sphere, but also outside the household, and at the boundaries of public and private. ${ }^{13}$ Ruddick also argues that 'maternal thinking', a mode of cognition arising from the practice of mothering, could, transformed and expanded, lead to a distinctive kind of peace politics. She anticipates the idea of a maternal performativity in suggesting that maternal acts could be subversive.

In addition, Ruddick opens up the possibility of new understandings of subjectivity as relational, or communal, a project which, as I have already hinted, would involve a challenge to the traditional public/private divide

${ }^{7}$ Jean Bethke Elshtain, Public Man/Private Woman: Women in Social and Political Thought, Princeton, NJ 1981, p. 4.

${ }^{8}$ As in the writings of Simone de Beauvoir, Shulamith Firestone, Betty Friedan and Germaine Greer.

${ }^{9}$ Euro-American feminist understandings of maternity can be extended and enriched by means of comparison with other cultures, a project that is only just beginning.

${ }^{10}$ See, for example, Jayne Buxton's Ending the Mother War: Starting the Workplace Revolution, London 1998.

${ }^{11}$ Butler, Bodies that Matter, p. 68.

${ }^{12}$ Sara Ruddick, Maternal Thinking: Toward a Politics of Peace, Boston, MA 1995, pp. 17 and 52.

${ }^{13}$ For example, Evelyn Nakano Glenn, 'Social Constructions of Mothering: A Thematic Overview', in Mothering: Ideology, Experience, and Agency, ed. Evelyn Nakano Glenn, Grace Chang, and Linda Rennie Forcey, New York/London 1994, pp. 1-29, here p.16. 
and allow a maternal agency to emerge. 'Maternal thinking', according to Ruddick, constitutes a relational mode of cognition, an idea also addressed by Christine Everingham in her 1994 examination of maternity. Everingham is concerned to expand pre-existing definitions of 'autonomy', understanding it herself as 'a form of subjectivity that is constructed in relation to another's claim to autonomy, in concrete social situations which are imbued with power'. ${ }^{14}$ This notion of a relational self is also to be found in the work of psychoanalyst Jessica Benjamin, who argues for the idea of 'mutual recognition' between mother and child. ${ }^{15}$ Benjamin opposes traditional psychoanalytic accounts which posit a passive mother, and proposes an 'intersubjective' view of the mother-child dyad.

Both Ruddick and Everingham depict the mother as an agent - as 'doing' maternity, to hark back to Butler ${ }^{16}$ - and mothering as a complex, historically contingent activity. But such an understanding can only be of value, or performative, if the material and discursive practices of a given society allow that. 'Theory' is partial and contingent. As the novels in question reveal, performativity is not always to be achieved. Produced at a time of social change with significant implications for mothering, ${ }^{17}$ the novels imply that despite the contemporary erosion of traditional boundaries between public and private, maternity was still at odds with agency. At the same time, they act to expose and criticise that state of affairs, according to my reading. I look firstly at three texts in which mothers are utterly abject (Elsner, Beutler, Pedretti), then at two which suggest more optimism with regard to maternal agency (Struck, Frischmuth), and finally at one which presents a challenge to the traditional public/private divide and puts forth the possibility of active feminist communities (Schroeder), whilst still demonstrating the problems involved in these projects.

In Gisela Elsner's Abseits (1982), the unlikeable middle-class heroine is shown to be the complicitous victim of social conventions. From the beginning of the novel, in which the drab suburb of Lerchenau is described with caustic detachment, what is offered is a bleak view of the individual at the mercy of hegemonic operations and of history. ${ }^{18}$ The maternal sub-

\footnotetext{
${ }^{14}$ Christine Everingham, Motherhood and Modernity: An Investigation into the Rational Dimension of Mothering, Buckingham 1994, p. 6.

${ }^{15}$ Jessica Benjamin, The Bonds of Love: Psychoanalysis, Feminism and the Problem of Domination, London 1990.

${ }^{16}$ Butler understands gender as 'a doing': 'There is no gender identity behind the expressions of gender; that identity is performatively constituted by the very "expressions" that are said to be its results' (Gender Trouble, p. 25.)

${ }^{17}$ See here Eva Kolinsky, Women in West Germany: Life, Work and Politics, Oxford 1989, chap. five, for background information relevant to Struck and Schroeder. Comparable shifts can also be detected in Switzerland (Beutler and Pedretti) and Austria (Frischmuth and Schroeder).

${ }^{18}$ Gisela Elsner, Abseits, Reinbek bei Hamburg 1982, pp. 5-8. Further references will be given in parentheses in the text.
}

(c) Blackwell Publishers Ltd 2002. 
ject is depicted as interpellated by ideology, in Althusserian terms. ${ }^{19}$ Elsner's is a not a simplistic constructivist position; rather, her novel is an examination of how the subject participates in the process of her own marginalisation. Indeed, the novel constitutes a forceful statement of this (Marxist) view.

It is only after the description of the suburb of Lerchenau and the introduction to the petty, ridiculous Besslein that we meet his wife, who is in the clinic, having just given birth. Thus, the story of Lilo, the mother, is framed, contextualised, a device which highlights her lack of agency. The early mention of the use of anti-depressants and of suicide in Lerchenau gives her story an air of inevitability and typicality. Lilo, it is implied, has no 'choice' but to follow the course described; this is not a liberal feminist view, then. Lilo's mothering is also contextualised. Maternity is sanitised and sequestrated in the clinic, a detail which already points to the marginalisation to which Lilo will be subjected (or to which she will subject herself). Lilo's concern with consuming - she has bought a new nightdress - and with her appearance, hints at the ideologies of capitalism and of patriarchy which influence her mothering; motherhood is depicted as intertwined with other institutions and ideologies. ${ }^{20}$ Later, consumerism offers Lilo escape from the monotony of her existence. Once again, the coextensive nature of different ideologies is revealed, as it is suggested that capitalism benefits from women's exclusion from the workplace.

Motherhood in the novel is an oppressive institution which places impossible expectations on women, as in the 1976 opinion of Adrienne Rich. ${ }^{21}$ It is imposed from without onto a passive subject; Lilo had not wished to have a child, but had been talked into it by those around her. Once a mother, she wonders why she is not as happy as everyone expects her to be (32). Elsner thus suggests the existence of a damaging 'maternal mystique', to borrow from Betty Friedan, with the figure of Irene Dülfer, the happy and dutiful wife and mother, representing the socially acceptable alternative to which Lilo cannot match up. At one point, Lilo is described as 'miming' 'die glückliche Mutter' (28); for her, then, maternal happiness is nothing but a compulsory performance, of a negative and unperformative kind. The idea of maternity as a social requirement is underpinned by Lilo's not daring to say that she does not wish for a second child, for fear that others will react 'wie auf einen Verstoß gegen die guten Sitten' (77).

Motherhood here spells consignment to a dreary realm of domesticity. Elsner's critique of the public/private divide echoes that of a diverse range

\footnotetext{
${ }^{19}$ See Louis Althusser, 'Ideology and Ideological State Apparatuses (Notes towards an Investigation)', in 'Lenin and Philosophy' and Other Essays, trans. Ben Brewster, London 1971, pp. 121-73, here p.160.

${ }^{20}$ Compare Barbara Katz Rothman, Recreating Motherhood: Ideology and Technology in a Patriarchal Society, New York/London 1989. Rothman argues that American motherhood is buttressed by three intertwined ideologies: those of capitalism, technology and patriarchy.

${ }^{21}$ Adrienne Rich, Of Woman Born: Motherhood as Experience and Institution, London 1977.
} 
of feminists such as Friedan, Elizabeth Janeway and Sheila Rowbotham, who argue that confinement to the private realm leads women to boredom, frustration and depression. Lilo's life as a mother is monotonous, and she is lethargic and depressed; 'maternal thinking' is rendered impossible, as Lilo is numbed and deadened. Her addiction to tranquilisers highlights her lack of agency, her dependence on props and palliatives, and her reluctance to leave the flat without grooming herself extensively points to her insecurity in the outside world. Although her domestic life is boring, anything else becomes threatening: 'Und je weniger in ihrer näheren Umgebung passierte, umso weniger zeigte sie sich den kleinen Abwechslungen gewachsen, die ihr Dasein mit sich brachte' (54). The variation on repetition which Butler defines as agency is not in question here, for Lilo's existence is stagnant and mechanical.

Elsner's novel suggests the powerfully coercive nature of the institutions of marriage and motherhood. Lilo's desire to work, for example, meets with resistance from her whole family. According to Wilma Besslein, a job cannot be reconciled with housework and childcare duties, and a child will suffer as a result of her mother working (103). Lilo does begin work again, however, and feels more confident and less depressed as a result of her job at a chemist's (105). But ultimately she never achieves autonomy or agency; at the end of the novel she is destitute and helpless. And her job actually helps her to commit suicide, since it means that she has lethal drugs at her disposal. Employment outside the home, then, does not offer an easy solution to maternal marginality. Unlike such liberal feminists as Friedan and Janeway, Elsner rejects individualistic solutions, and puts forth a bleak view of deeply ingrained, oppressive ideologies.

While Elsner may problematise individualism, her novel suggests that relationality and community are impossibilities. Lilo's mothering is characterised not by 'mutual recognition', but by hostility and distaste. And the two points are linked, according to my understanding of maternal agency - Lilo is devoid of the relational capacities which encourage social awareness and commitment. She begins to read the newspapers only in order to impress her lover, the superficial socialist Meichelbeck, and his friends (67). Her relationship with Meichelbeck over, she ceases to be interested in politics, for: 'Sie hatte solche Mühe, mit sich und mit ihrem Leben zu Rande zu kommen, daß ihr keine Kraft blieb, sich mit etwas zu befassen, das außerhalb ihres Privatbereichs lag' (134-5). Narcissism, then, is the consequence of limited occupations and status.

Lilo's confinement in a psychiatric institution is the logical continuation of her life 'abseits'. Imprisoned and in a passive, drugged state, Lilo begins to enjoy life in the institution: 'Vor allem genoß sie es, daß sie für nichts mehr die Verantwortung zu tragen hatte' (187). Paradoxically, it is only there that she finds a sense of community (188). Towards the end of the novel, when asked by a colleague if she wishes to join a trade union, Lilo declines (246). Her rejection of collectivity and of political involvement is typical of her narcissism. Mental illness and suicide are the conse- 
quences of patriarchal capitalism for Lilo, with psychological, economic, historical and class factors all coming into play. ${ }^{22}$ Capitalism, it is suggested here, renders maternal subjectivity malleable to the point of impotence.

Elsner's explicitly political analysis of mothering contrasts with the more lyrical, subjective narratives of Erica Pedretti and Maja Beutler, who, none the less, imply a critical awareness of maternal marginality. In Pedretti's Veränderung (1977) the maternal subject is depicted as shifting and in exile. The fluid world of the text is redolent of French feminist accounts of a pre-oedipal realm, suggesting a maternal subjectivity defined by silence and otherness. The text's narrator can be viewed as inhabiting a 'semiotic' realm, with the outside world, the 'Symbolic Order', representing a threatening, regulatory force. ${ }^{23}$ The external world, inasmuch as it figures in this highly subjective narrative, appears invasive, with its unavoidable noises and smells. The narrator appears to be sucked in by it when she looks outside. ${ }^{24}$ The public realm is associated with imposition, with control; a policeman had made regular appearances at the narrator's door, and she is aware of being seen returning home at night by neighbours $(28,27)$. The text thus implies the existence of an external sphere of masculine authority, of which the narrator is fearful and to which she has no access.

For the narrator is throughout the novel lethargic and isolated. She is a 'Stubenhockerin' (46), who finds it difficult to leave 'diese[ ] Höhle von Haus' (106). Lacking confidence and energy, she finds her work as an illustrator, architect and teacher demanding $(90,106)$. As in Elsner, work here offers little possibility of agency. The 'private' sphere also appears inimical to maternal agency. The flat is a space of uncertainty; it is replete with traces of the previous tenant, by whom the narrator is haunted. It is both enclosing - the narrator seeks a way out of it - and dilapidated, letting in rain (11-12, 15). Like Elsner, Pedretti implies the isolation of the modern mother, but here that isolation is threateningly incomplete, as the vestiges of the previous tenant and the encroaching rain suggest. The flat fails to provide a refuge from the outer world; for much of the narrative, work is being done on it, so that a sense of fragility and exposure is created. The flat is taken over by workmen, whose decisions the narrator is forced to accept, and she is physically unable to help her husband carry out improvements $(151,75)$. This particular 'semiotic' space offers no 'jouissance', but only powerlessness and even madness.

Just as the flat is open to invasion, so the narrator herself is vulnerable,

\footnotetext{
${ }^{22}$ Compare the deranged, alcoholic Gerti in Elfriede Jelinek's 1989 novel Lust, Reinbek bei Hamburg 1992. This novel terminates not with suicide, but with murder, as Gerti kills her son. Both Jelinek and Elsner thus suggest the impossible, unlivable nature of maternity in patriarchal capitalism.

${ }^{23}$ See here Julia Kristeva's 1977 'Stabat Mater', trans. Leon S. Roudiez, in The Kristeva Reader, ed. Toril Moi, Oxford 1986, pp. 160-86.

${ }^{24}$ Erica Pedretti, Veränderung oder die Zertrümmerung von dem Kind Karl und anderen Personen, Frankfurt a.M. 1977, p. 33. Further references will be given in parentheses in the text.
} 
even unstable. Her self-identity is weak; the boundaries between self and other are unclear, as are those between inner and outer. The figure of Frau Gerster, whose commonplace ramblings take up much of the narrative, dominates the narrator, beginning to enter her dreams and rob her of her creativity. The narrator is powerless to resist external influences; she cannot help observing others, for example (47). The fact that she had been a refugee ties in with the notion of the subject as unfixed and changing, as does the title of the novel. The narrator indeed muses: 'Nur wenige Sätze, eine beschriebene Seite, und meine Lage hat sich verwandelt', and later reflects upon 'die Veränderungen in dieser Straße, in diesem Haus und in mir' $(10,33)$. The appearance in her flat of one of her fictional characters, to whom she speaks, suggests a kind of schizophrenia.

This kind of multiplicity and lack of fixity does not result in a performative view of subjectivity; instead, it leads here to solipsism and stasis. In contrast to the officious, self-important Frau Gerster, who believes that one can help others if one possesses 'einen festen Charakter' (102) - an apparently enabling liberal humanist fiction - the narrator sees only obstacles when she considers effecting any improvement (103), thus lending weight to feminist critiques of the anti-humanism of postmodernism. The narrator recalls a communist friend of hers who died in an asylum, and goes on to muse how fatalistic her fictions are becoming (105). Here, fiction does not appear able to serve a performative function; it only reflects the narrator's lack of agency.

As in Elsner, community appears impossible, not least because of the narrator's unwillingness to form connections with others, her lack of relationality. Despite the lack of privacy in this neighbourhood $(37,173)$, no sense of community is established. The narrator is in fact glad that nobody knows her address, and grateful that she is not related to anyone in the vicinity, 'so bedeuten die Unterhaltungen und Beobachtungen nicht unbedingt Einmischung' $(65,41)$. And Frau Gerster, who bemoans the modern lack of family feeling and of community, is apparently rejected as a potential model. Performativity, then, is not to be achieved by Pedretti's mother; maternal subjectivity is here trapped in the demented semiotic. $^{25}$

In Maja Beutler's Fuss fassen (1980), there is a similar sense of entrapment and powerlessness, owing, in particular, to the heroine's illness. The medical reports which are interspersed throughout the novel, and the words of the doctors, suggest the existence of an external sphere of rationality and control, and contribute to the image of a passive maternal subject. While the novel might indeed be viewed as concerned more with disease than with mothering, the association of maternity with illness is itself significant, I would suggest, particularly given other texts' linkage of the two, for it highlights the abject quality of the maternal subject position.

\footnotetext{
${ }^{25}$ See Julia Kristeva, 'Stabat Mater', in which maternity is described as offering 'demented jouissan$c e$, p. 179.

(c) Blackwell Publishers Ltd 2002.
} 
In this text, as in Elsner's, employment outside the home signals a desire for agency on the heroine's part, a desire which is ultimately thwarted by illness. Although her husband does not deem her return to work essential, the narrator feels she needs it in order to live, and she urges her husband: 'du musst mich in die Welt hinausjagen, in die Wirklichkeit, ich muss einen Weg finden'. ${ }^{26}$ Thus Beutler's novel suggests a challenge to the traditional public/private divide, and the possibility of agency, but the text also reveals such agency to be elusive. In the first part of the novel, the narrator is returning to her place of work after an absence. The main narrative is interspersed with sections of scientific prose, in which experiments on an animal are described. The obvious analogy between the narrator, who is timid and fearful, and the 'Versuchstier' suggests a lack of agency on the woman's part. Images of confinement such as the animal's cage, and the glass door of the broadcasting house, serve to reinforce the effect of powerlessness (9). The narrator is not seen when she enters the room in which her former colleagues sit (22); her attempts at asserting herself fail, and she flees (26). But her eventual refusal to begin work again under the conditions proposed constitutes self-assertion. In response to her colleague's claim that she is reacting in an absurd fashion, the narrator answers: 'Reagieren? Das habe ich vierzig Jahre lang gemacht, immer nur reagieren. Jetzt...' (37).

But the rest of the novel suggests that the yearned-for 'Wirklichkeit', and the agency required to enter it, are not so easily attainable. Beutler's mother occupies a diseased and insane kind of 'semiotic' realm. In the next section of the novel we are plunged into a dream world in which the figure of an imaginary young girl dominates the narrator. As in Pedretti's novel, the self appears here as malleable and vulnerable, and as in Pedretti, there is a sense of invasion; relationality is not a positive, ethical ideal, but a threat. The idea of the heroine occupying a 'semiotic' space is reinforced later by the reference to a powerful 'Vatersprache'. This notion echoes Lacanian ideas concerning the Symbolic Order and its government by the Law of the Father. The narrator quotes the words of her dead father, whose influence appears great. She addresses him directly, musing on his words to her, and contrasting them with her own inarticulacy towards her children (59). The heroine's language, described as being like raw meat and suitable only for wolves, is, it is implied, primitive, uncivilised (62). Thus, it appears unable to participate in culture, let alone shape it; maternal performativity, then, is not to be achieved by discourse.

Women are associated in the text with nature, with a precultural state; the girl speculates: 'Vielleicht bauen wir Frauen immer den Garten von früher' (51). Later, the narrator appears to see her mother in the middle of a field, while her father is imagined in the house (90-1). The narrator herself wishes for a refuge in nature, desiring contact with the earth, which

\footnotetext{
${ }^{26}$ Maja Beutler, Fuss fassen, Berne 1980, p. 28. Further references will be given in parentheses in the text.
} 
she associates with her mother (99), and she increasingly takes comfort from the forest. When she is being treated in hospital, the narrator even imagines herself to be a wolf in front of her family's house, and she pleads with her husband to let her in (80-1). Her husband is perceived by her as constituting 'die Wirklichkeit' which is now unattainable for her (58); masculinity is associated with power, with agency. The heroine, on the other hand, feels that she has fallen out of the world - 'Kein Platz bei euch, die Wirklichkeit voll und besetzt' - and says to a friend: 'ich bin nicht die Welt, ich bin das andere' $(85,161)$. The 'semiotic' here is not inside the 'Symbolic Order', as in Irigaray's understanding, ${ }^{27}$ rather, it is outside, utterly other, and the mother remains abject.

Karin Struck and Barbara Frischmuth, on the other hand, tentatively suggest the possibility of a maternal agency, but their texts ultimately yield to, and, in doing so, critically expose, mothers' abjection. Struck's novel Die Mutter (1975) is another highly subjective work, but it contains many reflections on the exclusion of mothers from public life and culture generally; Struck's heroine Nora does attempt to challenge dominant ideologies directly, and 'maternal thinking' occasionally seems subversive and potentially performative. The novel's reliance on essentialism, however, suggests ultimately that maternal agency is not (yet) a viable proposition.

Struck's Nora, like Rich, suggests that the 'experience' of maternity has been distorted by the 'institution' which constructs it. This institution, in her view, enforces maternal marginalisation and muteness; mothers are 'ausgestoßen aus der Weltgeschichte', ${ }^{28}$ misrepresented in literature and silenced by the media. Nora's reflection that 'die Mutter ist eine Vorstellung', and her view that 'alles ist symbolisch. Es wird nur noch symbolisch gelebt und gegessen', suggest an awareness of the workings of ideology and the constructed nature of experience $(18,167)$. Her criticism of the 'Illustriertensprache der Distanz' (98) used to gloss over the experiences of pregnancy and birth also highlights the function of language in the construction of reality, implying a post-structuralist perspective. Struck's novel also puts forth the possibility of competing discourses, of challenges to dominant meanings. In response to what she perceives as society's denigration of maternal corporeality, Nora seeks to reclaim and celebrate certain words: 'Das schöne Wort biologisch, das schöne Wort weiblich, das schöne Wort kindlich wieder lieben lernen’ (206).

But Struck's novel also, and more often, implies a belief in the existence of a fixed, female essence which needs only to be uncovered for mothers to be liberated. Nora frequently links the mother to the notions of origin and 'Heimat', and associates a female essence with maternity (e.g. 265). Her rejection of objectivity, and her association of women with nature, are similarly risky: 'die Unterdrückung der Frau ist die Unterdrückung

\footnotetext{
${ }^{27}$ See here Judith Butler, Gender Trouble, p. 12.

${ }^{28}$ Karin Struck, Die Mutter, Frankfurt a.M. 1975, p. 28. Further references will be given in parentheses in the text.
}

(c) Blackwell Publishers Ltd 2002 
der Natur', it is claimed (277). Such links serve to consign women to a realm of irrationality and physicality, and to exclude the possibility of their participation in culture. In addition, Nora's assertion that 'viel war schon vor der Sprache, das meiste' (175), and her notion of a special kind of dialogue between mother and infant $(111,171)$, serve, like some French feminist accounts, to undermine any idea of competing discourses, and bespeak a wistful yearning for a space outside culture and reason.

Nora does explicitly criticise the public/private distinction, and the denigration of the latter term, at several points $(112,172,191)$. But she often refers vaguely to 'sie' or 'die Menschen' as the enemies of motherhood and children; her criticism is rather lacking in nuance, as in certain radical feminist accounts of patriarchy. The novel is mainly a record of Nora's thoughts, so that ideas of interaction, of collectivity, do not apply here; Nora may imagine demonstrations in which mothers demand recognition and reward for their work, but she does not act on her imaginings. Ultimately, Struck's critique of the social organisation of mothering leads only to a nostalgic yearning for a simple mode of life as led by the 'Volk' $(342,356)$, or to dreams of a precultural realm of infantile bliss. While relationality and community appear here as ideals, and while Nora is a thoughtful and critical subject, the novel's retreat into essentialism shows maternal agency to be a daunting aim. The final sentence of the novel 'Nicht geboren zu sein ist das höchste Glück' (385) - suggests the abject, unlivable nature of the maternal subject position.

In her Sternwieser-Trilogie, Barbara Frischmuth effects a gradual transition from the magical world of Die Mystifikationen der Sophie Silber (1976) ${ }^{29}$ to the more realistic setting of Kai und die Liebe zu den Modellen (1979). ${ }^{30}$ The novels deal with the ideas of agency and community, but, I would suggest, ultimately side-step these issues in favour of a resigned kind of essentialism.

In Amy oder die Metamorphose (1978), ${ }^{31}$ which acts as a stylistic and thematic bridge between the first and last works of the trilogy, a kind of maternal agency is suggested in Amy's agonising over whether to become a mother or not. The mother here is a reflective subject, and maternity is not simply imposed from without as it is in Elsner's text; it is, rather, the result of 'choice' on the part of the individual woman, a liberal view which Amy explicitly defends to the socialist Herwater (A285). But the issue of choice is problematised in the next novel, in which Amy reflects that 'choice' is always contingent on context, and in particular upon the decisions of others (K209). Mothering is presented here as embedded in

\footnotetext{
${ }^{29}$ Barbara Frischmuth, Die Mystifikationen der Sophie Silber, 2nd edn, Munich 1995.

${ }^{30}$ Barbara Frischmuth, Kai und die Liebe zu den Modellen, Munich 1997. References to this novel will be preceded by $K$ in parentheses in the text.

${ }^{31}$ Barbara Frischmuth, Amy oder die Metamorphose, 4th edn, Munich 1982. References will be preceded by $A$ in parentheses in the text.
} 
particular cultural contexts and as shaped by the mother's subject position, a view reminiscent of Ruddick and Everingham.

Notions of community also figure in Amy. Herwater, for example, talks of 'Kommunalpolitik', stressing how collective needs are met by collaborative efforts (A221-2). Earlier in the novel, Amy herself had mused upon her need for others, going on to reflect: 'Alles ist so sehr unter Kontrolle, und dennoch, auch die Kontrolle kann versagen' (A69). The text thus offers a view of the individual maternal subject involved in relationships with others - as in the work of Everingham and Ruddick - and as part of a society which is both rigid and unfixed, that is, open to change. Amy indeed understands society as in flux, opining: 'Ich glaube nur an Änderungen, nicht an die große Einheit' (A286) - a post-structuralist position which implies a complex view of culture as in process.

The text also suggests a relational view of identity. Amy's growing commitment to those around her signals her entry into a modernist community built on trust. ${ }^{32}$ It also, in her view, helps her to clarify her own identity $(A 161)$. But this patchy narrative, consisting of disparate tales told by different characters, 'eine Kette von oberflächlichen Kurzgeschichten', as one critic puts it, ${ }^{33}$ ultimately does little to explore human interaction and agency. While relationality is put forth as an ideal, it is not successfully realised by the text or by Amy. In particular, Amy's origins in the spirit world suggest that community and agency in the 'real' world are not thinkable. While Amy's new human form might be seen as indicating women's entry into the Symbolic Order from a feminine realm of irrationality and fluidity, the device also, and more significantly, in my reading, offers Frischmuth an essentialist refuge. The issues of choice and agency are here softened and blurred, as a magical hideaway from the real world is implied.

In Kai, however, there is explicit criticism of the marginalisation of mothers. Amy's struggles as a mother living apart from her partner serve as a criticism of the existing order, which overburdens women and isolates mothers and their children. In Amy's view, modern women 'lassen sich [...] zu einer Art von Stärke zwingen, die sehr aufreibend ist' (K57). She thus anticipates feminist critiques of the 'double burden' imposed upon working mothers. 'Die Maschine Mutter' (K102), Amy claims, is patronised and ignored, a complaint reminiscent of Struck. Women's confinement to the private sphere is presented as having negative psychological effects. As in Nancy Chodorow's psychoanalytic account, the absent father is associated by the child with power and activity and is idealised, with longlasting and far-reaching social consequences (K211). ${ }^{34}$ And paternity here

\footnotetext{
${ }^{32}$ See here Anthony Giddens, Modernity and Self-Identity: Self and Society in the Late Modern Age, Cambridge 1991, p. 6.

${ }^{33}$ Karin Kathrein, 'Verwandlung zum Menschen', in Barbara Frischmuth, ed. Kurt Bartsch, Graz/Vienna 1992, pp. 127-9, here p.128.

${ }^{34}$ Nancy Chodorow, The Reproduction of Mothering: Psychoanalysis and the Sociology of Gender, Berkeley 1978 , p. 80. 
is characterised by inattentiveness and laziness, which means that maternal work is not supported by or shared with the male parent.

Frischmuth's text consequently seeks to envisage different family structures, offering new 'Modelle'. The notion of 'eine radikal persönliche Organisation' (K203), based on forming connections amongst individuals, is significant in this context. Linked to the idea of more fluid family structures is the assertion that society should become more child-centred (K71). Amy imagines living in the country, in a friendly and supportive community (K15), and considers the possibility of living in a commune (K111). But the novel does not go beyond such suggestions of an alternative social structure. To Amy, her ideas of another way of life seem 'utopisch, um nicht zu sagen lächerlich' (K9). Frischmuth's rejection of utopian models suggests a resignedly conservative position, and again, the use of the fantastic offers consolation. Amy's dream towards the end of the novel, in which she is at one with her fellow fairies and spirits, offers the comfort of a fantastical refuge. Where Struck's Nora finds solace in nature and dreams of 'Heimat', Amy ultimately shuns the real world altogether. While Frischmuth's texts do attempt to draw up a performative maternal agency, they also demonstrate the social, psychological and political impediments to such agency, with modern forms of individualism, heterosexuality and masculinity being revealed as obstacles.

Margot Schroeder's Der Schlachter empfiehlt noch immer Herz (1976) goes further in its depiction of female agency and community. The novel interweaves documentary material concerning the campaign to keep open a women's refuge with the personal reflections of the first-person narrator, Ola. Thus, 'personal' and 'political' are here blended together, as they are in the depiction of Ola's mothering. In her dealings with Kai, her son, Ola is explicitly aware of how others will judge her. ${ }^{35}$ As in Elsner and Struck, then, the individual mother must contend with prevalent ideologies of maternity, with the 'institution' of motherhood, which is shown to involve hard work, entrapment and low social status $(46,41,32)$. Ola's mother represents a willing victim of this institution. She urges her daughter to devote herself to Kai and accuses her: 'Ihr habt kein Familienleben mehr' (141). But Ola herself is reflective and challenging; as in Ruddick's view, mothering involves thought and judgement. In addition, the difference between mother and daughter suggests that the institution of motherhood is in process, that change is possible.

Schroeder's text also shows us specific 'action contexts' ${ }^{36}$ which raise questions of choice and autonomy. For example, Ola wavers between the idea that she should clean up, even though it is the turn of her husband, Martin, and the reflection that she should liberate herself from domestic

\footnotetext{
${ }^{35}$ Margot Schroeder, Der Schlachter empfiehlt noch immer Herz, Munich 1976, p. 13. Further references will be given in parentheses in the text.

${ }^{36}$ A term taken from Everingham, who uses it as a way of conceptualising agency without relying on the the public/private distinction (Motherhood and Modernity, p. 124).
} 
drudgery. As Martin has gone out with Kai, thereby leaving Ola with time to work, the issue is not clear-cut (11-12). Later, Ola says of feminists: 'Wir sind zu dogmatisch' (45), in response to a friend's statement that she feels ashamed of ironing her boyfriend's trousers. Schroeder's text, then, offers a nuanced view of ideology as something unfixed and dependent upon context. It also shows the subject as constituted in and through relationships with others, as in the views of Everingham and Benjamin.

As has been pointed out: 'Das Individuum in Schroeders Texten ist nie außerhalb der Grenzen symbolischer, zwischenmenschlicher und sozioökonomischer Strukturen'. ${ }^{37}$ Ola herself is aware of such structures, telling Martin: 'Wir haben schließlich Umwelt auf dem Buckel' (134). In the text, religion and the law represent discourses which perpetuate traditional views of women as mothers and wives $(12,13)$. The influence of environment is apparent in the figure of Kai, who has already taken on misogynistic views $(30,32)$. Ola, angered by Martin's attempts to fashion Kai into a conventional man, explicitly reflects upon the contingent nature of her mothering: 'Und du willst Kai zu einem neuen Menschen erziehen? Was heißt das, Ola? Das heißt nichts. Du hast kein Programm. Du hast ihn und du hast Dich. Aber genügt das gegen eine programmierte Umwelt?' (31). Women are indeed shown to be marginalised by the dominant culture; they are 'Sperrmüll der Geschichte' (37), at the edges of history and society. Female concerns are given scant attention by the press (46), and where feminists are depicted, their ideas are distorted and belittled (99). In addition, women's domestic roles make it difficult for them to engage in political activity $(42,157)$; the very structures which they wish to combat prevent them from doing so.

Unlike Struck's and Frischmuth's novels, however, Schroeder's text depicts a feminist counter-public sphere. For Ola, the campaign to keep open the women's refuge represents a turning-point, a step towards a politically active way of life (99). The documentary material which intersperses the narrative serves as a constant reminder of feminist participation in the public sphere. It also implies the possibility of competing discourses, as do the graffiti which Ola reads on a toilet wall, a suggestive detail (21). Ola's reflections concerning feminism also suggest such a (post-structuralist) perspective. Feminism, ponders Ola, must be both utopian and pragmatic (34). It must operate within existing structures while seeking to forge its own methods of operation (92). That is to say, the text does not depict a 'semiotic' realm which exists outside of 'patriarchy'; rather, it shows power to function in and through the discourses and practices of a given society.

Feminism here is heterogeneous and in process, but it is also characterised by collective action with specific aims. The notion of collectivity is not

\footnotetext{
${ }^{37}$ Evelyn Torton Beck and Biddy Martin, 'Westdeutsche Frauenliteratur der siebziger Jahre', in Deutsche Literatur in der Bundesrepublik seit 1965: Untersuchungen und Berichte, ed. by Paul Michael Lützeler and Egon Schwarz, Königstein/TS. 1980, pp. 135-49, 146.
}

(c) Blackwell Publishers Ltd 2002. 
romanticised, however. Throughout the novel, characters interact, often clashing with each other. An infinity of opposing perspectives is thus implied; consensus, community, are shown to be complex, difficult entities. At a gathering of friends, Ola becomes aware of the disparity between each individual's perceptions of reality (89): relationality is here complicated and problematised by the introduction of the issue of difference, but still it is ultimately validated. The text also puts forth alternatives to current parenting arrangements, stressing the notion of community. Like Frischmuth's Amy, Ola wishes her son to have contact with other adults (85). The nuclear family is depicted as oppressive and constraining, and Ola's own marriage is highly problematic.

Schroeder's text also exposes both the friction and the harmony between personal and political, problematising the boundary between the two categories. For example, Ola's reactions to the women's movement are interesting in their ambiguity, and are occasionally obscured by or confused with personal emotions. Ola also asks herself if she has simply taken on board certain feminist slogans unquestioningly $(13,15)$; that is, she wonders if she has been interpellated by the ideology of feminism. Such a speculation is redolent of Butler, who asserts: 'Feminist critique ought $[\ldots]$ to understand how the category of "women", the subject of feminism, is produced and restrained by the very structures of power through which emancipation is sought'. ${ }^{38}$

Unlike Struck, Schroeder refuses essentialism and offers a view of the subject as precarious and in process. Ola looks at her reflection in the mirror at several points, as if to establish her own existence. She frequently addresses herself in the second person, appearing as split, plural. When Kathrin and Ola playfully adopt the roles of a chat-show host and his guests (161-3), Schroeder is pointing to the constructed nature of identity. The text, then, does not posit a female essence outside of or before patriarchy, but conceives of gender as a continuing, potentially subversive, performance within it. At the end of the novel, Ola describes herself as 'eine Landkarte aus Zielen' (167), an image suggestive of plurality, motion and agency.

Elsner, Pedretti and Beutler, then, posit a passive and marginal maternal subject. In different ways, their novels explore and expose the operations of exclusion, implying the need for a revision of 'traditional' social arrangements, and for the development and enactment of what I have theorised as a 'maternal performativity'. Struck and Frischmuth are more optimistic, but not much; both ultimately depict the mother as outside of culture. It is only in Schroeder that we find a maternal subject who is active, and even performative. Even Schroeder's novel, however, highlights the difficulties for mothers involved in politics; maternity, it appears, is not easily reconcilable with public, or political, activity. In general, then, the traditional public/private opposition holds sway in these troubling

\footnotetext{
${ }^{38}$ Judith Butler, Gender Trouble, p. 2.
} 
works, and what emerges is a shared critical awareness of mothers' traditional, and continuing, isolation and abjection. The texts themselves, however, can be viewed as participants in a performative discursive community, as can this article, so that the marginality which the novels depict need not be viewed as the end of the story. 